\title{
Religious Extremism Factors and Preventive Strategies: Al-Istishraq (Orientalism) as Impetus to Religious Extremism
}

\author{
Mohd Solahuddin Shahruddin ${ }^{1}$, Mohd Norazri Mohamad Zaini', Mohd Yusra Abdullah', \\ Mohd Paidi Norman², Muaz Mohd Noor ${ }^{3}$, Che Zarrina Sa'ari.4
}

${ }_{1}$ Postgraduate Students, Academy of Islamic Studies, University of Malaya, 50603 Kuala Lumpur, Malaysia. 2Lecturer, Academy of Contemporary Islamic Studies, UiTM, 40450Shah Alam, Selangor, Malaysia. ${ }^{3}$ Lecturer, Academy of Contemporary Islamic Studies, UiTM, Alor Gajah, Melaka, Malaysia. ${ }^{4}$ Associate Professor, Department of Aqidah and Islamic Thought, Academy of Islamic Studies, University of Malaya, 50603 Kuala Lumpur, Malaysia. ${ }^{5}$ Senior Lecturer, Department of Aqidah and Islamic Thought, Academy of Islamic Studies, University of Malaya, 50603 Kuala Lumpur, Malaysia

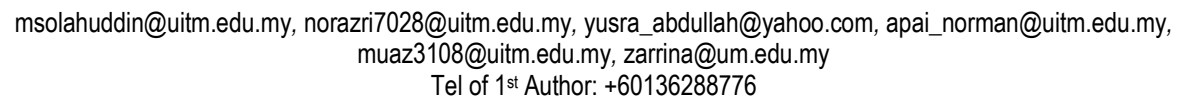

\begin{abstract}
Al-Istishraq is one of the subversive elements that have been corrupting Muslims into becoming radicalised, since the times of colonialism until present times. They denied the contribution of Islam in knowledge and civilizations resulting precedence in Muslim civilization becoming unclear. Al-Istishraq succeeds in misguiding and affecting integration among Muslims as Muslims blindly follow the ideologies. Prevention on such matter is challenging as scholars fail to provide comprehensive guidelines. The extremism numbers are alarming. It raises hatred and destruction of others. This article shall briefly review the impact and cause of al-Istishraq, and Muslims weaknesses in comprehend the spread.
\end{abstract}

Keywords: Al-Istishraq; Islamic knowledge; Muslims, orientalism; religious extremism

eISSN: 2398-4287 @ 2020. The Authors. Published for AMER ABRA cE-Bs by e-International Publishing House, Ltd. UK. This is an open access article under the CC BYNC-ND license (http://creativecommons.org/licenses/by-nc-nd/4.0/). Peer-review under responsibility of AMER (Association of Malaysian Environment-Behaviour Researchers), ABRA (Association of Behavioural Researchers on Asians) and cE-Bs (Centre for Environment-Behaviour Studies), Faculty of Architecture, Planning \& Surveying, Universiti Teknologi MARA, Malaysia.

DOI: https://doi.org/10.21834/ebpj.v5iSI1.2299

\subsection{Introduction}

The term al-istishraq (in English is orientalism) is from Arabic word al-istishraq. Its root word ishraq is added with letters alif, sin and ta' means the quest for light or guidance from the East, as in the sun rises from the East (Che Hussain, 2008). The term dirasat al-istishraq (oriental studies) is a from Western scholarship (adopted from Islam) that study Eastern values and various disciplines of knowledge such theology, archaeology, religions, literature, politics and economy from a Western perspective. Through dirasat al-istishraq, the West has surreptitiously planned implicit strategies of ghuzwah al-fikr (intellectual corruption) to weaken the minds of Muslim society. Such consistently renewed plans are to ascertain that the dawlah Islamiyyah (Islamic state) is not established until the end. The current scenario has seen Muslims being ceaselessly bombarded by accusations of terrorisms and condemnations by the West.

Ironically, there arise groups of Islamists who have been taken in by the Western deception to misguidedly retaliate with terror and shadid (hard) approach. The rise of self-destructive religious extremism is a goal of such Western agenda that has become a hidden fire that may fuel endless conflicts among Muslims in particular.

History of religious conflicts indicated that they were triggered as a consequence of mutual suspicions between various religious adherents, and due to unbridled fanaticism. The rises of religious extremists are also a consequence of the capitalist economy and 
blaming what is perceived as unjust state and authority. Religious extremism is not a phenomenon among Muslims only, but also those of other religions as well.

There are extremists among the Muslims, Jews, Christians, Hindus and Buddhists. The Buddhist in Myanmar lately became notorious for their inhumane treatment of the Muslim Rohingyas. Although religious extremism has become identical with various religions, yet in global discourse, it is often associated with Muslim extremists, mainly post 9/11. All Muslims must stop the al-Istishraq surreptitious corruption of jihad (holy war) as an only way to spread Islam to the world.

\subsection{Endless Terrorism}

Conversation on religious-based terrorism is becoming virulent among various world communities irrespective of age, education and religions. It brings negative perception and cynical view of Islam, particularly to the misconception of jihad, even among Muslims themselves.

Previous research on Western conspiracies against Islam, particularly the 11th September in New York (Hirschkorn, 2003), saw it as an excuse to attack Islam, purportedly disguised to eradicate terrorism in several Muslim countries (Wintour et al., 2001), such as Afghanistan, Iraq and now Syria. It is becoming more evident that presently, the hidden hands are still at work in some Muslim countries such as Iraq, Iran, Tunisia, Yemen, Egypt (Fraser, 2013) Libya, and Syria (Blight et al., 2012).

Genocide is being committed against Muslims, especially against innocent public members. This atrocity has compelled some Muslims to take up arms to defend themselves. However, this has been manipulated as terrorism by the West. Those Muslim countries inflicted by various conflicts are still have not found their peace and bloodshed among the Muslims continue.

The West saw the Muslims reactive self-defence as terrorism, and this is viewed as al-makr (deceived) by the West. It perverted the view of jihad with their misperception of terrorism as inherent in Islam. This medium is a severe misconception of the message of Islam because Islam itself means peace. Peace as in the Arabic word is "salam". Islam, therefore, is not terrorism.

Research also revealed an injunction by Allah S.W.T that relate to al-makr issues that Muslims must unite to correct the misperception propagated by the West to destroy the credibility of Islam and the nation (Zaini, 2014). Dr Abdullah Azzam initiated the call for global jihad in the 1980s (McGregor, 2003). Even though he was killed in 1989, the call was still being echoed by groups such as the al-Qaeda led by Osama bin Laden (McGregor, 2003). The global jihad, according to Abdullah Azzam (2013), should be based for the sake of Allah the Almighty, and Islam only, excluding all forms of national sentiments that blind oneself.

According to Abdullah Azzam, jihad is an obligation that must be performed by Muslims, after the attestation of iman (faith), preceding other pillars of Islam. According to Ibn Taymiyyah (2001), jihadis as "There is none more obligatory after attesting your iman to Allah SWT, more than repelling enemies who attacked your honour and religion."

Oppressions and injustices in Muslim societies have raised their spirit to engage in jihad in several countries in the Middle East, even establishing several global jihad movements (al-Zawahiri, 2001). These movements, also came about to fight all forms of foreign interventions, giving birth to a series of armed conflicts such as in Iraq, Palestine, Syria, Afghanistan and several other countries. These groups were called al-mujahidin by many Muslims. Unfortunately, many Muslim revolution movements were labelled as terrorists by the United States and their allies, causing other countries just to follow suit, including Arab countries.

In the Palestinian issues, the West biased view was evident when their staunch ally, Israel committed atrocities on the Muslims in Gaza, and it was not labelled as terrorism at all. This medium is significantly different when the Palestinians were labelled as terrorists when they rose against the Israeli occupants when they are actually only defending themselves, their rights and lands.

This is due to the fact that terrorism is defined according to the Western powers vested security interests (Kapitan, 2004). Hamas victory in the election 2006 had increased the concern of the West over the intifada movement against Israel, causing it to be declared as terrorists (Beinin \& Hajjar, 2014). Now wreaking havoc in the Middle East is a change called ISIS (The Islamic State of Iraq and alSham) that also call for international al-jihad. ISIS even declared the re-establishment of the Islamic caliphate in Iraq and Syria (Withnall, 2014). However, ISIL has been notorious with gross radicalism and extremism, shocking in the brutal killings of their captives and kidnapped victims and public members (CBS News Website, 2014). Such radicalism is of grave concern that is totally opposed to the teaching of the Prophet Muhammad (peace be upon him).

\subsection{Al-Istisyrâq Orientalism as Impetus to Extremism}

In "Buhuth fi al-Tabshir wa al-Istishraq", a work on missionary and orientalism by Hasan 'Abd al-Ra'uf, the term orientalist is generally referred to non-Arabs who study knowledge of the orient such as language, religion, history and cultures. While, a renowned scholar, Edward W. Said (2011) defined orientalists as those who study Eastern or oriental knowledge from Western thought and values. A more generic term that is a scholar is presently used to identify orientalist works.

Al-Istishraq may begin at the family level, then educational institutions, down to the public, and up to the level of government leadership. The elements in al-istishraq are firstly motivated by religion, secondly by knowledge/scholarship, thirdly due to economy, and fourthly, politics. Many undesirable issues have aroused, for the motives of al-istishraq are to surreptitiously capitalise on the weaknesses of among Muslims that lead to division among Muslim society.

How did the al-istishraq influence Muslim minds? The al-istishraq used a hermeneutic approach originated from the Western JudeoChristian religious thought. This influence turned some Muslim religious school system to be shadid (hard) with daily activities solely for the other-worldly aim to attain paradise. 
Children who are too young to understand the ghaybiyyat (metaphysic) matters are literally taught to fear, and not with proper gradual understanding befitting their age. Overly literal and simplistic reactions based on irrational fear or favour of heaven and hell are by Muslims of various ages are consequences intended by al-istishraq.

Some of the Muslims primary education is focusing more on literal and simplistic either-or matters purportedly lead to rewards of either heaven or hell. That all Western created subjects and theories must be destroyed at once by the use of force. That task is made obligatory to all Muslims; that, those taking exceptions shall be punished in hell. These so-called rules are regarded as a fatwa (a ruling on the point of Islamic law) and must be implemented without fail (Muhamad, 1981). Delightfully, al-istishraq deemed Eastern society as easily influenced by their deceptive baits.

Targets of al-istishraq are children, women and youth who are fanatics for rewards of paradise. Young children are raised and brainwashed into radicalism, through a diet of condemnation, terrorism and punishment for their daily physical and psychological consumption. Worse, when children also become second liners to their mujahid (holy warfighter) parents in fights in Syria and Iraq (Utusan Malaysia, 2014). It is greatly alarming to watch the viral video of Muslim children being trained to use firearms, declaring they free of any citizenship and burning of their passports.

Propagators of al-istishraq also charade themselves as intellectuals with pleasant personality and articulate speech delivery (Abdul Mun'im, 2001). These projected personas of an al-istishraq orientalist are often attractive to women who could be misguided by such appearances.

\subsection{Recurrence of Bloody History}

There is a need to include in our education, courses such as comparative religions and Islamic thought, particularly the ethics of war in Islam. This knowledge may help Muslims, particularly in Malaysia re-evaluate their understanding of jihad al-qital (fighting a holy war) in defence of one's country and religion without the use of the radical approach. There is a need to clarify to Muslim society, issues of terrorism, radicalism and extremism vis a vis Islamic injunctions. Particularly to those with the potential to carry out jihad al-qital as encouraged by Islam. There is a need to correct negative public view on the issue of jihad, such as the stereotype and paranoia, in proper Islamic perspective. There should be exposure of the insidious plan by certain groups to intimidate Muslims and ensure Western hegemony on Muslims and the world generally. All political, economic, social and academic manipulations must be checked. Muslims must be made aware of these issues. There is a need to include in our education, courses such as comparative religions and Islamic thought, particularly the ethics of war in Islam. This knowledge may help Muslims, particularly in Malaysia re-evaluate their understanding of al-jihād qitālin in defence of one's country and religion without the use of the radical approach. There is a need to clarify to Muslim society, issues of terrorism, radicalism and extremism vis a vis Islamic injunctions. Particularly to those with the potential to carry out aljihād qitāl as encouraged by Islam. There is a need to correct negative public view on the issue of jihad, such as the stereotype and paranoia, in proper Islamic perspective. There should be exposure of the insidious plan by certain groups to intimidate Muslims and ensure Western hegemony on Muslims and the world generally. All political, economic, social and academic manipulations must be checked. Muslims must be made aware of these issues.

\subsection{Statistics of World Peace}

Table 1.0: List of Less Peaceful Countries due to Terrorism and Conflict

\begin{tabular}{llll}
\hline & & Position by Countries & \\
\hline 1. & Bahrain & $10 .$. & Mali \\
2. & Azerbaijan & 11. & Burundi \\
3. & Saudi Arabia & 12. & Mexico \\
4. & Ethiopia & 13. & Venezuela \\
5. & Chad & 14. & Israel \\
6. & Eritrea & 15. & Palestine \\
7. & India & 16. & Colombia \\
8. & Philippines & 17. & Turkey \\
9. & Egypt & 18. & Lebanon \\
\hline
\end{tabular}

(Source: Global Peace Index 2017)

Table 2.0: List of Least Peaceful Countries due to Terrorism and Conflicts

\begin{tabular}{clcl}
\hline & & Position by Countries & \\
\hline 1. & North Korea & 9. & Somali \\
2. & Russia & 10. & Yemen \\
3. & Pakistan & 11. & South Sudan \\
4. & Dem. Rep. Cong & 12. & Iraq \\
5. & Ukraine & 13. & Afghanistan \\
6. & Central African Rep. & 14. & Palestine \\
7. & Sudan & & \\
8. & Libya & & \\
\hline
\end{tabular}


Table 3.0: Country with most attacks, 2014, global terrorism database.

\begin{tabular}{rccc}
\hline No. & Country & \#Attacks & \# Fatalities \\
\hline 1. & Iraq & 3925 & 13076 \\
2. & Pakistan & 2146 & 2409 \\
3. & Afghanistan & 1820 & 5411 \\
4. & Ukraine & 889 & 1396 \\
5. & Somalia & 862 & 1582 \\
6. & India & 859 & 488 \\
7. & Yemen & 760 & 1349 \\
8. & Libya & 729 & 690 \\
9. & Nigeria & 713 & 7774 \\
10. & Philippines & 597 & 472 \\
\hline
\end{tabular}

(Source: Global Peace Index 2017)

In comparing extremism perpetrated between Muslims and non-Muslims, an issue that should be emphasized is the concept of 'extreme' itself. Extremism and radicalism are taken from the word al-ghuluw (excessive). According to the New York Times, cases of extremism committed by non-Muslims have caused twice as many deaths compared to those perpetrated by Muslims, particularly in the United States, driven by racism, bigotry and anti-government. Many other cases are neither committed by nor related to Muslim extremists nor jihadist (Scott Shane, 2015); such cases instead involved the Christians, Jews, Hindus and others. Statistical evidence will show that extremist attacks related to al-jihad are only half of the offences committed by the Christians or right leanings perpetrators.

Indeed, it is unfair to see terrorism solely from the view of colonialists and Western powers. Both are also committed acts of terrorism in conflicts such as wars, purported to eradicate other terrorism with their brand of terrorism. Their oppression and excesses often went beyond the harms perpetrated. This can be seen in the number of deaths and casualties inflicted by Western armies in Muslim countries such as Iraq, Afghanistan, Syria and others.

Recent history will attest that the Western powers have destroyed almost 37 countries in pursuit of their vested interests that involved nearly 20 million victims, with subsequent casualties are continuing. By comparison, the highest incidences of terrorism perpetrated among the Western powers, the United States are far ahead in causing deaths and destructions.

\subsection{Conclusion}

Thus it is evident that the al-istishraq (orientalism) has surreptitiously been subverting the Muslim nation, shaken their faith and open the way for terrorism. Even though al-istishraq is often associated with jihad (holy war), it is not its only focus. It also sows other elements to subvert Muslims and society, such as the creation of negative perceptions of people of different religions toward Islam. Prophet Muhammad emphasised that to maintain peace and harmony the Muslim community must have embraced true tawhid (unity of God) to be able to understand the meaning and pure forms of al-jihad and al-salam for the benefits of the Muslims nation. Jihad is undoubtedly not the practice of terrorism as perverted insidiously through al-istishraq.

\section{References}

'Abdul Mun'im, F. (2001). Min Iftira'at al-Mustashriqin 'Ala al-Usul al-'Aqidah fi al-Islam. Riyadh: Maktabah al-Ubaykan.

Al-Azhary, U. S. (2015). Islam Radikal: Telaah Kritis Radikalisme Dari Ikhwanul Muslimin Hingga ISIS. Trans. M. Hidayatulloh. Abu Dhabi: Dar al-Faqih Publication \& Distribution.

Al-Ghazali, A. H. (1957). Ihya ‘Ulum al-Din. Semarang: Maktab Karya Putra.

Al-Mubarakfuri, S. R. (2010). Al-Rahiq al-Makhtum. Mansurah: Dar al-Wafa'.

Al-Qaradawi, Y. (2008). Ilbn al-Qaryah wa al-Kuttab, Malamih Sirah wa Masirah, 3. Cairo: Dar al-Shuruq.

Al-Suhaylī, A. Q. A. A. (1998). Al-Rawd al-'Unuf, 2. Cairo: Dar al-Kutub al-Hadithah.

Al-Zawahiri, A. F. (2001). Taht Rayah al-Nabi. Al-Sharq al-Awsat, 2-12.

Azzam, A. (2013). Tarbiyah Jihadiyah. 1-6 vols. A. Al-Qudsi (Trans). Solo: Jazera.

Beinin, J. \& Hajjar, L. (2014). Palestine, Israel and the Arab-Israel Conflict: A Primer. n.p: Middle East Research \& Information Project.

Blight, G., Pulham, S. \& Torpey, P. (5 January 2012). Arab spring: An interactive timeline of Middle East protests. In The Guardian Website. Retrieved from http://www.theguardian.com/world/interactive

Charles, W. \& Amjad, A. (2009). Jihad and Just War Theory: Dissonance dan Truth. Dialogue: A Journal of Theology, 48(3), 239-248.

Che Hussain, M. F. (2008), Awas! Ancaman OrientalisTerhadap Kita. Kuala Lumpur: Grup Buku Karangkraf.

Firestone, R. (1999). Jihad: The Origin of Holy War in Islam. New York: Oxford University Press. 
Fraser, S. (20 August 20133). Turkey's prime minister says Israel behind Egyptian leader's ouster. In Global News Website. Retrieved from http://globalnews.ca/news/790683/turkeys-prime-minister-says-israel-behind-egyptian-leaders-ouster/.

Hirschkorn, P. (October 29, 2003). New York reduces the 9/11 death toll by 40. In Cable News Network (CNN). Retrieved from http://edition.cnn.com/2003/US/Northeast/10/29/wtc.deaths/?t=123

ISIS Attacks in Syria and Iraq May be Emerging Genocide. (4 August 2014). In CBS News Website, Retrieved from https://www.cbsnews.com/video/isis-attacks-in-syria-and-iraq-may-be-emerging-genocide/

Ibn Hisham, A. M. (1975). Al-Sirah al-Nabawiyyah,1. Beirut: Dar al-Jil.

Ibn Taymiyyah (2001). The Religious and Moral Doctrine of Jihaad. Birmingham: Maktabah Al Ansaar Publications.

Ibrahim, B. (2007). Melampau: Punca-punca, Ciri-ciri \& Cara Mengatasinya. Kuala Lumpur: Al-Hidayah Publication.

Kapitan, T. (2004). "Terrorism" as a Method of Terrorism. In G. Meggle (Ed.). Ethics of Terrorism \& Counter-Terrorisme. Ontos: Heusenstamm.

Lings, M. (1983). Muhammad: His Life Based on the Earliest Sources. Rochester: Inner Traditions.

Mas'od, M. A. (2013). Diskusi Isu Aqidah dan Pemikiran Semasa di Malaysia. Putrajaya: JAKIM.

McGregor, A. (2003). Jihad and the Rifle Alone: 'Abdullah `Azzam and the Islamist Revolution. Journal of Conflict Studies, 23(2), 92-93.

Muhamad, Bahiy. (1981). Pemikiran Islam Kontemporari dan Hubungannya Dengan Kolonialisme Barat. Jakarta: Panjimas.

Said. E. (2001). Orientalisme: Menggugat Hegemoni Barat dan Mendudukan Timur sebagai Subjek. Yogyakarta: Pustaka Pelajar.

Shane, S. (24 June 2015). Homegrown Extremists Tied to Deadlier Toll Than Jihadists in U.S. Since 9/11. In New York Times Website. Retrieved from https://www.nytimes.com/2015/06/25/us/tally-of-attacks-in-us-challenges-perceptions-of-top-terror-threat.html?mcubz=0

Wintour, P. et al. (7 October 2001). After the September Eleventh Terrorist Attacks on America, It's time for war, Bush and Blair Tell Taliban. In The Guardian. Retrieved from http://www.theguardian.com/world/2001/oct/07/politics.september11.

Withnall, A. (30 June 2014). Iraq Crisis: Isis Declares Its Territories a New Islamic State with 'Restoration Of Caliphate' in the Middle East. In Independent. Retrieved from http://www.independent.co.uk/news/world/middle-east/isis-declares-new-islamic-state-in-middle-east-with-abu-bakr-albaghdadi-as-emir-removing-iraqand-syria-from-its-name-9571374.html

Zaini, M. N. M. (2014). Al-Makr Terhadap Rasulullah S.A.W.: Analisis Menurut Perspektif Pemikiran Islam. (Master Dissertation, Master of Usuluddin, department of Aqidah and Islamic Thought, Academy of Islamic Studies, University of Malaya).

Zulheddy. (2012). Sejarah Islam Lengkap. Kuala Lumpur: Penerbitan Seribu Dinar. 